\title{
KEMENANGAN PETAHANA DALAM KONTESTASI PILKADA SERENTAK 2018: DITINJAU DARI PERSPEKTIF POWERCUBE
}

\author{
Andi Muh. Dzul Fadli \\ Universitas Lakidende, Unaaha Sulawesi Tenggara, \\ Email: dzulfadliandimuh@yahoo.com \\ Indrawan Tobarasi \\ Universitas Lakidende, Unaaha Sulawesi Tenggara, \\ Email: indrawan.t2684@gmail.com

\section{Komeyni Rusba} \\ Universitas Balikpapan, Kalimantan Timur \\ E-mail: komeyni@uniba-bpn.ac.id
}

\begin{abstract}
Abstrak
Pemilihan Kepala Daerah (Pilkada) di Indonesia telah dilaksanakan secara serentak sebanyak 3 (tiga) kali yakni pada tahun 2015, 2017, dan 2018. Secara filosofis, pilkada serentak dilaksanakan untuk mengefisiensikan anggaran, menekan pelanggaran dan kecurangan (electoral malpractices) serta meminimalisir gejala sosial-politik dari adanya pilkada yang sebelumnya dilaksanakan secara terpisah berdasarkan periode akhir masa jabatan setiap kepala daerah. Berangkat dari fenomena persentase kemenangan para petahana di berbagai kontestasi pilkada 2018, maka menarik dikaji untuk memaknai faktor-faktor yang menyebabkan kemenangan para petahana tersebut. Dalam kajian ini digunakan pendekatan kualitatif terhadap berbagai literatur terutama yang bertalian dengan pengoperasian bentukbentuk kekuasaan dalam perspektif teori kubus kekuasaan (the powercubetheory).Penulis mengumpulkan danmereview literatur kontemporer yang relevan dengan fenomena yang dikaji secaradialektis dengan cara melakukan reviewdan menganalisisnya secara kritis atasberbagai sumber literatur yang terpilih. Hasil kajian menunjukkan bahwa ada 3 (tiga) bentuk kekuasaan sebagai faktor kemenangan petahana, yakni:Pertama,
\end{abstract}




\section{Andi Muh. Dzul Fadli, dkk: KEMENANGAN PETAHANA....}

bentuk kekuasaan yang terlihat (visible power)ialahkesempatan untuk menarik simpati masyarakat melalui jualan program pembangunan yang telah dilaksanakan sebagai investasi politik. Kedua, bentuk kekuasaan yang tersembunyi(hidden power) ialah politisasi birokrasi melalui mobilisasi aparatur sipil negara, monopoli dukungan partai politik, dan kooptasi terhadap penyelenggara pemilu. Ketiga, bentuk kekuasaan yang tidak terlihat (invisible power), melalui peranan pemuka agama dan pemangku adat untuk menanamkan nilai-nilai dan ideologi merupakan modalitas politik petahana sebagai konsekuensi dari stratifikasi sosial-masyarakat.

\section{Kata Kunci: Pilkada, Petahana, Bentuk Kekuasaan.}

\section{Pendahuluan}

Pemilihan kepala daerah (Pilkada) serentak ketiga di Indonesiatelah dilaksanakan pada 27 Juni 2018. Ada 171 daerah dengan rincian 17 provinsi, 39 kota, dan 115 kabupaten yang menyelenggarakan Pilkada langsung di tahun 2018. ${ }^{1}$ Pada periode sebelumnya, pilkada dilaksanakan secara terpisah, mengikuti periode akhir masa jabatan seorang kepala daerah. Sebagaimana dalam UU No. 10/2016 tentang perubahan kedua UU No. 1/2015 tentang penetapan peraturan pemerintah pengganti UU No. $1 / 2014$ tentang pemilihan gubernur, bupati, dan walikota menjadi undang-undang.Menariknya di pilkada tahun 2018, partisipasi petahana sebagai kandidat mengalami peningkatan. Pilkada 2017, persentase keikutsertaan petahana sebesar 16,61 persen,

\footnotetext{
${ }^{1}$ Andhika Prasetia, "Ini 171 Daerah yang Gelar Pilkada Sserentak 27 Juni 2018”, diakses dari https://news.detik.com/berita/d-3479819/ini-171-daerah-yanggelar-pilkada-serentak-27-juni-2018, pada 27September 2018

Jurnal TAPIs Vol. 14 No.02 Juli-Desember 2018 


\section{Andi Muh. Dzul Fadli, dkk: KEMENANGAN PETAHANA....}

sedangkan pada Pilkada 2018, partisipasi petahana meningkat menjadi 19,49 persen. $^{2}$

Calon petahana paling banyak terdapat di pilkada kabupaten/kotayakni calon petahana bupati dan wakil bupati berjumlah 106orang.Serta calon gubernur dan wakil gubernur petahana sebanyak 13 orang. ${ }^{3}$ Peningkatan partisipasi calon petahana tentu didasarkan pada kalkulasi peluang kemenangan. Peluang tersebut dapat diukur melalui kebijakan-kebijakan pada masa pemerintahan, capaian program pembangunan, politisasi birokrasi, sampai pada kesiapan dari aspek finansial petahana sebagai konsekuensi tingginya biaya demokrasi langsung (direct democracy) pada momen pilkada. Selain itu, pragmatisme partai politik untuk tidak mengambil resiko mendukung kandidat yang berpeluang kalah adalah faktor yang tidak dapat dikecualikan.

Tolok ukur lainnya ialah menguatnya public truth (kepercayaan publik) terhadap kinerja petahana. ${ }^{4}$ Kemudian adanya potensi manipulasi Pilkada oleh kepentingan memenangkan petahana,sebab didukung oleh kelemahan dalam aturan pada proses rekruitmen penyelenggara pemilu. ${ }^{5}$ Oleh

\footnotetext{
${ }^{2}$ Azhar Azis, "Calon Kepala Daerah Pengusaha Dominasi Pilkada 2018', diakses dari https://nasional.kompas.com/read/2018/07/26/18520301/64kepala-daerah-petahana-terpilih-pada-pilkada-serentak-2018, pada 27 September 2018

${ }^{3}$ Kompas TV, "Ini dia Para Petahana Pilkada 2018",diakses dari http://www.tribunnews.com/nasional/2018/06/27/ini-diapara-petahana-pilkada-2018, pada 2Oktober 2018

${ }^{4}$ Rex Tiran, "Kemenangan Petahan dan Demokrasi Lokal dalam Pilkada Kabupaten Kupang Tahun 2013" Tesis Program Magister Ilmu Politik Universitas Airlangga (Surabaya: Fakultas Ilmu Sosial dan Ilmu Politik, 2013), hlm. 1

${ }^{5}$ Amri Yusra danIkhsan Darmawan, "Kepentingan Petahana dalam Manipulasi Pilkada Labuhan Batu Selatan 2015",Jurnal Wacana Politik,2(2), 74-87 (Oktober 2017), hlm. 85
}

Jurnal TAPIs Vol. 14 No.02 Juli-Desember 2018 


\section{Andi Muh. Dzul Fadli, dkk: KEMENANGAN PETAHANA....}

karena itu, secara konseptual menyiratkan bahwa ada beberapa potensi-potensi yang dapat dieksplorasi dan eksploitasi petahana dalam memenangkan kontestasi pilkada. Meskipun pada konteks lainnya, petahana dapat dikalahkan oleh pasangan calon lain, yang disebabkan oleh beberapa faktor lain seperti faktor internal dan eksternal, perilaku pemilih, pengelolaan media, dan pengawalan suara yang berlapis. ${ }^{6}$

Potensi kemenangan petahana dapat juga disebabkan oleh kemampuan petahana dalam memperoleh dukungan para elit lokal seperti pemuka agama, pemangkut adat, ataupun daricivil society yang ada di daerah selain dari dukungan dan bekerjanya mesin partai politik pengusung. Hal tersebut dimaknai sebagai kemampuan petahana dalam mengindoktrinasi ataupun mengkooptasi elit lokal berdasarkan bentuk-bentuk kekuasaan yang diimplementasikan. Seperti penelitian tentang elite lokal yang berbasis pesantren bersinergi dengan kekuatan politik, terutama dalam mendukung petahana yangbertarung mempertahankan kekuasaannya. ${ }^{7}$

Pada artikel, penulis akan menguraikan faktor-faktor yang menyebabkan kemenangan petahana dengan menggunakan perspektif teori kubus kekuasaan (the powercube theory)dengan bertolak pada persentase atau tingkat keterpilihan yang signifikan berdasarkan hasil penetapan pemenang oleh KPU masing-masing daerah. Secara empirik, berikut ini persentase empat pasang calon petahana.

${ }^{6}$ Mhd. Rafi Yahya, "Faktor yang Mempengaruhi Kemenangan Jefry Noer dan Ibrahim Ali di Pilkada Kabupaten Kampar”,Jurnal Dinamika Pemerintahan,1(1), 42-49 (Januari 2018), hlm. 42

${ }^{7}$ AbdulChalik, "Elite Lokal Berbasis Pesantren Dalam Kontestasi Pemilihan Kepala Daerah Di Jawa Timur", KARSA: JurnalSosial dan Budaya Keislaman, 23(2), 363-381 (Desember 2015), hlm. 363. 
Andi Muh. Dzul Fadli, dkk: KEMENANGAN PETAHANA....

\begin{tabular}{|c|c|c|c|c|}
\hline No. & $\begin{array}{c}\text { Nama Calon } \\
\text { Petahana }\end{array}$ & Pilkada & $\begin{array}{c}\text { Jumlah } \\
\text { Suara } \\
(\%)\end{array}$ & $\begin{array}{c}\text { Partai Politik } \\
\text { Pengusung }\end{array}$ \\
\hline 1 & $\frac{\frac{\text { Ganjar }}{\text { Pranowo }}}{\text { Taj Yasin }}$ & $\begin{array}{c}\text { Jawa } \\
\text { Tengah }\end{array}$ & $58,78 \%$ & $\begin{array}{l}\text { PDI-P, } \\
\text { Demokrat, } \\
\text { Golkar, PPP, } \\
\text { NasDem }\end{array}$ \\
\hline 2 & $\begin{array}{l}\text { Rahmat } \\
\text { Effendi - Tri } \\
\text { Adhianto }\end{array}$ & $\begin{array}{c}\text { Kota } \\
\text { Bekasi }\end{array}$ & $68,29 \%$ & $\begin{array}{l}\text { PPP, } \\
\text { Demokrat, } \\
\text { PAN, Hanura, } \\
\text { PDIP, PKB, } \\
\text { Nasdem, } \\
\text { Golkar }\end{array}$ \\
\hline 3 & $\begin{array}{l}\text { Bima Arya } \\
\text { Sugiarto- } \\
\text { Dedie } \\
\text { Rachim }\end{array}$ & $\begin{array}{l}\text { Kota } \\
\text { Bogor }\end{array}$ & $43,64 \%$ & $\begin{array}{l}\text { PAN, } \\
\text { Demokrat, } \\
\text { Golkar, } \\
\text { NasDem, } \\
\text { Hanura }\end{array}$ \\
\hline 4 & $\begin{array}{l}\text { Sunjaya } \\
\text { Purwadi } \\
\text { Sastra - } \\
\text { Imron }\end{array}$ & $\begin{array}{c}\text { Kab. } \\
\text { Cirebon }\end{array}$ & $45 \%$ & PDI-P \\
\hline
\end{tabular}

Sumber: Data olahan tahun 2018

Berdasarkan data-data tersebut di atas, menyiratkan bahwa secara kuantitatif keempat pasangan calon petahana mendapatkan perolehan suara yang signifkan dengan dukungan partai politik yang dominan, terkecuali pasangan Purwadi Sastra-Imron yang diusung tunggal oleh PDI-P pada pilkada Kabupaten Cirebon. Oleh karena itu, menarik untuk dianalisis terhadap capaian yang didapatkan para petahana dalam membantu persentase atau besaran kemenangan pada pilkada serentak tahun 2018 .

Untuk menganalisis fenomena tersebut, maka penulis ini akan menggunakan teori powercubesebagai sebuah kerangka 


\section{Andi Muh. Dzul Fadli, dkk: KEMENANGAN PETAHANA....}

pemikiran untuk menganalisis melalui tiga dimensi bentuk kekuasaan, yaitu kekuasaan yang terlihat (visible power), kekuasaan yang tersembunyi (hidden power), dan kekuasaan yang tidak terlihat (invisible power). Karena menggunakan teori powercube sebagai kerangka analisis dianggap relevan dalam memaknai kekuasaan dalam konteks politik lokal melalui proses demokratisasi di daerah. ${ }^{8}$ Teori ini dapat membantu untukmemetakan hal-hal yang berperan dalam kekuasaan, para aktor di dalamnya, persoalan dan situasi yang melatarbelakanginya, bahkan kemungkinan untuk melakukan perubahan secara tepat dan evolusioner. Teori ini sekaligus mengantarkan pada alasan mengapa seseorang berpotensi memenangkan pertarungan dalam politik. ${ }^{9}$

Tulisan ini bertujuan untuk mengeksplorasi secara teoritik sebab-sebab tentang penggunaan bentuk-bentuk kekuasaan petahanamenggunakan kerangka teori powercube. Pada

\footnotetext{
${ }^{8}$ Abd. Halim,Politik Lokal: Pola, Aktor dan Dramatikalnya (Yogyakarta: LP2B, 2014), hlm. 55. Teori powercube adalah teori yang dicetuskan oleh John Gaventa sebagai bagian dari analisi baru untuk memahami kekuasaan. Teori ini memiliki 3 (tiga) bagian atau dimensi yaitu dimensi level, dimensi ruang, dan dimensi bentuk (lihat selengkapnya pada JohnGaventa,"Finding the Spaces for Changes: A Power Analysis"IDS Bulletin, 37(6), 23-33, November 2006).Teori powercube telah mendapat kritik dari Cox karena teoripowercube sebagai analisis kekuasaan seperti pada konteks politik global, analisis yang sediakan sangat terbatas dalam melihat perubahan sosial, terutama bagaimana menganalisis tentang agensi pada dimensi keamanan, dimensi praksis, dan dimensi pedagogi (lihat selengkapnya Laurence Cox, "Powercube: understanding power for social change", Journal of Political Power, 4(2), 301-307, (August 2011). Namun menurut penulis, menggunakan teori powercube dianggap relevan dan kontekstual untuk menganalisis dinamika politik lokal.

${ }^{9}$ Abdul Chalik,Op.cit., 365
}

Jurnal TAPIs Vol. 14 No.02 Juli-Desember 2018 


\section{Andi Muh. Dzul Fadli, dkk: KEMENANGAN PETAHANA....}

umumnya, beberapa artikel tentang kemenangan petahana dalam pilkada disebabkan faktor internalyaitu penguatan tim pemenangan untuk memenangi pilkada. ${ }^{10}$ Sedangkan dalam perspektif powercube bahwa pada konteks politik lokal, hidden power sebagai modal kekuatan politik para elit. ${ }^{11}$

Penulis sedikit berbeda dengan argumen-argumen pada umumnya seperti diuraikan di atas. Jika pada studi-studi sebelumnya menyatakan bahwa faktor internal dan adanya hidden powerpetahanaagar bisa memenangipemilihan kepala daerah, maka artikel ini berargumen bahwa kemenangan petahana padapilkada 2018 disebabkan adanya bentuk-bentuk kekuasaan lain seperti visible power (kekuasaan yang terlihat) dan invisible power (kekuasaan yang tidak terlihat).Oleh sebab itu, artikel ini merupakan pemaknaan terhadap bentuk-bentuk kekuasaan petahana pada kontestasi pemilihan kepada daerah secara serentak pada tahun 2018. Sehingga sekaligus mengantarkanpada alasan mengapa seseorangbisa memenangkan pertarungan dalampolitik.

\section{Metode}

Dalam artikel kajian ini, penulis menggunakan pendekatan kualitatif melalui studi literatur dan dokumentasi yang bertalian dengan fenomena kemenangan para petahana dalam kontestasi pilkada serentak tahun 2018. Studi literaturdilakukan dengan mengumpulkan danmereview literatur serta kontemporer yang relevan denganfenomena yang dikaji khususnya yang bertalian dengan teori kubus kekuasaan the powercubetheory).Dialektikadibangun dengan cara melakukan

${ }^{10}$ PujiAstuti dkk, "Strategi Pemenangan Petahana dalam Pemilihan Umum Kepala Daerah Kabupaten Ngawi 2010", Journal of Politic and Government Studies, (2013)

${ }^{11}$ Welhelmina Selfina Beli, "Hidden Power dalam Politik Pemekaran di Nusa Tenggara Timur",Jurnal of Government JOG, 2(1), 1-17 (Desember 2016), hlm. 2 


\section{Andi Muh. Dzul Fadli, dkk: KEMENANGAN PETAHANA....}

reviewdan menganalisnya secara kritis atasberbagai sumber literatur yang terpilih.

\section{Pembahasan}

\section{Kontestasi Pilkada Serentak 2018: Kemenangan Petahana}

Berbeda dengan pilkada sebelumnya di Indonesia yang dilaksanakan secara mandiriatau terpisah berdasarkan periode akhir masa jabatan masing-masing kepala daerah. Secara filosofis, efisiensi anggaran, menekan pelanggaran dan kecurangan (electoral malpractices) sertameminimalisir gejala sosial-politik akibat adanya pilkada sebagai argumentasi yang fundamental dalam melaksanakan pilkada serentak tahap awal pada tahun 2015, termasuk pada tahun 2018 dari 171 daerah baik pada tingkat provinsi dan kabupaten/kota. Dari aspek partisipasi pemilih, menurut salah satu komisioner KPU RI bahwa pada pilkada 2018 secara nasional tingkat partisipasi pemilih sebanyak 73,24\%. Mengalami penurunan dibandingkan pilkada 2017 dengan tingkat partisipasi sebesar 74\%dari jumlah DPT. ${ }^{12}$

Partisipasi masyarakat untuk mengikuti pemilihan kepala daerah tersebut pada dasarnya menjadi tolok ukur partisipasi politik dalam demokratisasi di daerah.Melalui penyelenggaraan pemilu yang demokratismerupakan salah satu parameter kualitasdemokrasi. Tingginya partisipasi politikmasyarakat dalam pemilu menunjukkan bahwa masyarakatmengikuti, memahami dan ikut sertadalam kegiatan pemilu. ${ }^{13}$ Selain itu, menurut Moon et. al bahwa partisipasi politik masyarakat dapat membantu membentuk identitas kolektif, serta mencapai keadilan sosial dan

\footnotetext{
${ }^{12}$ Merdeka,"KPU sebut partisipasi pemilih di Pilkada 2018 capai 73,24 persen", diakses dari https://www.merdeka.com/politik/kpu-sebut-partisipasi-pemilihdi-pilkada-2018-capai-7324-persen.html, pada 5 Oktober 2018

${ }^{13}$ Ratnia SolihahdanSiti Witianti, "Permasalahan dan Upaya Mewujudkan Pemilu Demokratis di Indonesia Pasca Reformasi",Jurnal Bawaslu, 3(1), 13-33 (Juni 2017), hlm. 23
} 


\section{Andi Muh. Dzul Fadli, dkk: KEMENANGAN PETAHANA....}

kesetaraan di seluruh kelas, gender dan etnis. ${ }^{14}$ Oleh karena itu, meningkatkan partisipasi masyarakat dalam pemilu (voter turnout) adalah aspek yang tidak kalah penting dari penyelenggaraan pemilu untuk membentuk identitas kolektif. Selain dari permasalahan terkait pemiluyang penuh dengan kecurangan (flawedelections).

Identitas kolektif dari partisipasi politik berfungsi untuk membangun sistem yang demokratis sebagaipencapaianterhadap manfaat yang terkait dengan masyarakat itu sendiri melalui penyaluran hak pilih. ${ }^{15}$ Selanjutnya bahwa yang menyebabkan masyarakat untuk tidak menggunakan hak pilihnya secara sederhana diklasifikasikan kedalam dua kelompok besar yaitu faktor dari internal (bersumber dari dirinya)yang disebabkan oleh faktor teknis dan faktor pekerjaan. Sedangkan faktor ekternal (sebab yang datang dari luar dirinya) ialah adanya faktor administrasi, sosialisasi, dan politik masyarakat. ${ }^{16}$

Dengan menurunnya partisipasi politik masyarakat tersebut, maka ada hal yang dianggap belum selesai atau belum dicapai dalam pilkada kali ini. Karena secara representatif pada konteks demokrasi langsung (direct democracy)bahwa setiap pejabat publik, tidak terkecuali kepala daerah membutuhkan partisipasi pemilih sebagai bentuk daulat masyarakat. Oleh karena itu, menurut penulis bahwa beberapa faktor yang menyebabkan rendahnya partisipasi tersebut disebabkan minimnya hasrat politik kekuasaan seseorang untuk menjadi calon kepala daerah. Selain itu, 'gemuknya' atau mengerucutnya dukungan partai politik kepada calon petahana adalah permasalahan lain pada konteks

\footnotetext{
${ }^{14}$ Bruce E. Moon, et.al,"Voting Counts: Participation in the Measurement of Democracy",Studies in Comparative International Development, 41(2), 3-32 (April 2006), hlm. 30

${ }^{15}$ Ibid, hlm. 31

${ }^{16}$ Bismar Arianto, "Analisis Penyebab Masyarakat tidak Memilih dalam Pemilu"Jurnal Ilmu Politik dan Pemerintahan, 1(1), 51-60(2011), hlm. 56
} 


\section{Andi Muh. Dzul Fadli, dkk: KEMENANGAN PETAHANA....}

ini. ${ }^{17}$ Sehingga menyebabkan kesungkanan dan pesimisme politik dengan adanya dominasi petahana dalam merangkul dan menggalang dukungan partai politik.

Selanjutnya hasil rilis dari Lingkaran Survei Indonesia (LSI) bahwa kemenangan petahana dalam pilkada seperti pada tahun 2015 disebabkan oleh beberapa faktor. Pertama, karena masyarakat merasa puas atas kinerja kepemimpinan petahana selama menjabat. Kedua, petahana lebih dikenal oleh masyarakatyakni popularitas sebagai modal politik.Ketiga, petahana dianggap telah menguasai dan mampu menjangkau semua segmen pemilih. Keempat, petahana mampu menggerakan tokoh informal maupun formal seperti birokrasi. Kelima, petahana ini lebih siap secara finansial. ${ }^{18}$

Uraikan LSI tersebut terutama pada faktor ketiga, keempat, dan kelima menyiratkan bahwa kemenangan petahana merupakan sesuatu yang terencana dan telah dipersiapan secara matang. Sebab kekuasaan politik yang dimiliki oleh kandidat petahana adalah keniscayaan untuk menaikkan elektabilitasnya melalui bentuk-bentuk kekuasaan yang dimilikinya. Bentuk-bentuk kekuasaan baik kekuasaan yang terlihat (visible power), kekuasaan yang tersembunyi (hidden power), dan kekuasaan yang tidak terlihat (invisible power). Sehingga secara faktual, hasil dari pilkada serentak 2018 sebagai kemenangan para petahana.

${ }^{17}$ Penulis menggunakan frasa 'gemuk' yang mengandung arti bahwa pragmatisme partai politik saat ini cenderung untuk mendukung calon petahana dengan pertimbangan peluang kemenangan.Tanpa keberanian dalam memberikan edukasi politik kepada masyarakat khususnya menawarkan seseorang yang dianggap baru tetapi memiliki integritas, rekam jejak dan kapabilitas.

${ }^{18}$ Ardi Mandiridan Erick Tanjung, "LSI: 70 Persen Petahana Menang dalam Pilkada Serentak"diakses dari https://www.suara.com/news/2015/12/10/161341/lsi-70-persenpetahana-menang-dalam-pilkada-serentak, 3Oktober 2018

Jurnal TAPIs Vol. 14 No.02 Juli-Desember 2018 


\section{Andi Muh. Dzul Fadli, dkk: KEMENANGAN PETAHANA....}

Sebagai contoh, pada pilkada 2015 ada $82,5 \%$ petahana yang kembali bertarung, dan $63,2 \%$ petahana terpilih kembali. Sementara, pada pilkada serentak 2017 ada 65 petahana kepala daerah dan 20 petahana wakil kepala daerah yang bertarung, dan yang terpilih kembali sebanyak 48 orang atau $56,47 \% .^{19}$ Sedangkan di pilkada 2018, ada 64 kepala daerah yang berstatus sebagai petahana memenangkan pilkada pada daerah masingmasing, ${ }^{20}$ serta ada 11 petahana unggul lawan kotak kosong. ${ }^{21}$

Data-data tersebut menunjukkan bahwa majunya seorang petahana dalam kontestasi pemilihan secara langsung seperti pada pertarungan pilkada tidak luput dari modal politik,menjadi prasyarat yang harus dimiliki oleh setiap kandidat. Karena secara elektoral, ada ruang-ruang yang mesti dicapai agar memenangkan pertarungan politik. Oleh sebab itu, bentuk-bentuk kekuasaan dianggap sebagai titik tolak seorang petahana baik pada proses kandidasi sampai pada treatment terhadap konstituen pada hari pemilihan.

\section{Kekuasaan yang Terlihat (Visible Power)}

Kontestasi pilkada adalah pertarungan antar-aktor untuk merebut hati masyarakat sebagai pemilih yang diharapkan akan

${ }^{19}$ Anwar Saragihdan Barry Calvin Ginting, "Proyeksi Mewujudkan Pemilu Berintegritas Lewat Netralitas Aparatur Sipil Negara di Pilkada Serentak 2018"Jurnal Bawaslu, 3(3), 351-362 (Juni 2017), hlm. 352

${ }^{20}$ Luthfia Ayu AzanelladanRetia Kartika Dewi, "64 Kepala Daerah Petahana Terpilih pada Pilkada Serentak 2018" diakses dari https://nasional.kompas.com/read/2018/07/26/18520301/64kepala-daerah-petahana-terpilih-pada-pilkada-serentak-2018, pada 5Oktober 2018

${ }^{21}$ Yandri Daniel Damaledo, "11 Petahana Unggul Lawan Kotak Kosong Versi Hitung Cepat KPU" diaksesdari https://tirto.id/11-petahana-unggul-lawan-kotak-kosong-versihitung-cepat-kpu-cM9Y, pada 4 Oktober 2018

Jurnal TAPIs Vol. 14 No.02 Juli-Desember 2018 


\section{Andi Muh. Dzul Fadli, dkk: KEMENANGAN PETAHANA....}

linier dengan perolehan suara secara siginifikan. Sebagaimana diketahui bahwa pertarungan politik secara simetris dapat terjadi bila para kandidat tidak memiliki kekuatan politik pada perspektif kekuasaan. Seperti tidak adanya peluang memanfaatkan kekuasaan pada pemerintahan baik pada konteks eksekutif dan legislatif. Sedangkan pertarungan secara asimetris dapat terjadi bila salah satu kandidat tertentu memiliki kekuasaan pada pemerintahan, seperti halnya pada pilkada serentak2018 dimana salah satu pasangan calon memiliki kekuasaan politik baik di eksekutif dan legislatif pemerintahan.

Dalam tinjauan kekuasaan bahwa lembaga, aktor dan kepentingan merupakan unit-unit penyusun bentuk kekuasaan yang terlihat, sebagai representasi kontestasi antar-aktor kekuasaan. ${ }^{22}$ Posisi calon petahana diuntungkan dari jabatan yangmelekat di dalam status sosial-masyarakatyakni sebagai pemimpin di suatu daerah. Bila ditinjau dari bentuk kekuasaan yang terlihat (visible forms of power),calon petahana secara langsung memiliki kesempatan untuk menarik simpati masyarakat melalui jualan program yang telah direncanakan ataupun program pembangunan yang telah dilaksanakan.

Selain daripada itu, kehadiranpemimpin (sebagai petahana) di tengah-tengah masyarakatmenjadi social-capital(modal sosial) yang dapat disebut sebagaiinvestasi politik dalam merebuthati dan simpati masyarakat pada pemilu berikutnya. ${ }^{23}$ Karena secara konseptual, ada tiga modal yang harus dimiliki oleh para calon yanghendak mengikuti kontestasi pilkadasecara langsung yaitu modal politik (political capital), modal sosial(social capital), dan modal ekonomi (economicalcapital). ${ }^{24}$ Oleh sebab itu, terbukanya

${ }^{22}$ Abd.Halim,Op.cit., 55-56

${ }^{23}$ Khoirondan Ahmad Siboy, "Kemenangan Petahana (Incumbent) pada Pilkada 2015 di Kota Surabaya dan Kabupaten Malang: Strategi Politik dan Marketing Politik",Jurnal Ilmu Administrasi Publik, 3(1), 1-10 (April 2018), hlm. 4

${ }^{24}$ KacungMarijan, Sistem politik Indonesia: Konsolidasi

Jurnal TAPIs Vol. 14 No.02 Juli-Desember 2018 
peluang menjadi nilai tambah dan pijakan petahana untuk mensosialisasikan dirinya sendiri dalam memengaruhi pola pikir masyarakat. Sehingga kontestasi di pilkada oleh para-aktor khususnya petahana dapat terlihat secara visual.

Ada berbagai rupa dan jenis dari bentuk kekuasaan yang terlihat dilakukan oleh seorang kepala daerah yang berstatus sebagai petahana di dalam pilkada langsung. Sebagai contoh sosialisasi atau kampanye kepala daerah terhadap predikat opini Wajar Tanpa Pengecualian (WTP)dalam pertanggungjawaban atas Laporan Keuangan Pemerintah Daerah (LKPD) pada tahun anggaran tertentu dengan mengikuti standar akuntansi pemerintahan.Selain itu, dalam bentuk lain ialah penghargaan piala adipura terhadap suatu kota di Indonesia yang berhasil dalam kebersihan serta pengelolaan lingkungan perkotaan yang diselenggarakan oleh Kementerian Kehutanan dan Lingkungan Hidup.

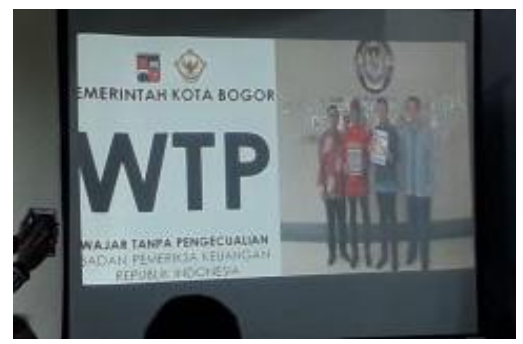

Gambar 1. Suasana Pemaparan Keberhasilan Pemerintah Kota

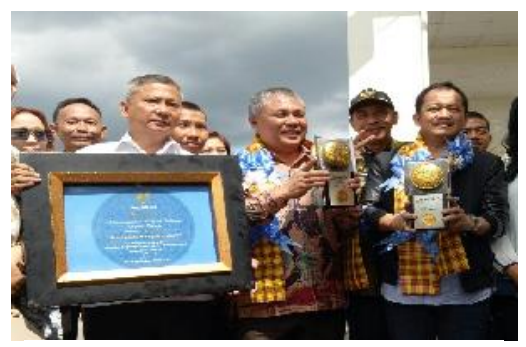

Gambar 2. Suasana Penjemputan Piala Adipura Kabupaten

Bentukkekuasaan ini biasanya mencoba mengubah 'apa, siapa, dan bagaimana' kebijakan itu menjadi lebih akuntabel. ${ }^{25}$ Faktor petahana menjadi salahsatu bukti kuatnya pengaruh kekuasaandalam politik daerah, mendukung

Demokrasi Pasca-Orde Baru,(Jakarta: PT. Kencana Prenada Media Group, 2010)

${ }^{25}$ CeciliaLuttrell et.al,"The Power Cube Explained", The Poverty-Wellbeing Platform, 3 (November 2007)

Jurnal TAPIs Vol. 14 No.02 Juli-Desember 2018 


\section{Andi Muh. Dzul Fadli, dkk: KEMENANGAN PETAHANA....}

terciptanyasimpul jaringankekuasaan dan pendanaan sebagai kunci dalamkemenangan petahana. ${ }^{26}$ Selain itu, petahana mampu mengkonversi kekuasaan politiknya dengan memvisualisasikan sesuatu yang dianggap sebagai prestasi dalam pelaksanaan pemerintahan. Tak diragukan bahwa hal itu tidak menghindarkan suatu analisis yang lebih mendalam tentang makna dibalik prestasi yang diperoleh. Karena pada dasarnya segala sesuatunya dapat dimanipulasi sesuai kebutuhan penguasa dalam hal ini petahana pada konteks pilkada langsung.

\section{Kekuasaan yang Tersembunyi (Hidden Power)}

Fakta menarik dari hasil pilkada serentak tahun 2018 ialah kemenangan kotak kosong dan dominannya kekalahan petahana untuk pemilihan gubernur. Akan tetapi fakta lain yang menjadi penting pula untuk dianalisis ialah tingkat partisipasi petahana sebagai peserta pilkada yang mengalami peningkatan dibandingkan pilkada tahun 2017. Sertaadanya 11 petahana yang unggul atas kotak kosong. Fenomena tersebut dapat dianalisis dengan menggunakan teori-teori kekuasaan. Salah satunya dengan menggunakan perspektif hidden power.

Secara konseptual, penggunaan bentuk kekuasaan yang tersembunyi (hidden forms of power) bertujuan untuk mempertahankan kepentingan seseorang atau kelompok melalui penciptaan halangan atau gangguan yang dapat membendung partisipasi kritis masyarakat. ${ }^{27}$ Dalam kontestasi pilkada sebagai arena perebutan kekuasaan, maka halitu dapat berlangsung secara simetris ataupun secara asimetris antar-kandidat. Proses perebutan kekuasaan politik dalam momentum pilkada dimulai sejak kandidasi calon. Konstruksi sistem pemilu di Indonesia dengan dibolehkannya calon tunggal, menyebabkan adanya kotak kosong pada kertas suara, sebagai konsekuensi tanpa adanya rivalitas kandidat.

\footnotetext{
${ }^{26}$ Abdul Chalik,Loc.cit.

${ }^{27}$ Abd. Halim,Op.Cit., hlm. 61
} 


\section{Andi Muh. Dzul Fadli, dkk: KEMENANGAN PETAHANA....}

Namun fenomena tersebut, hakikatnya adalah aktualisasipetahana merupakan bentuk kekuasaan secara tersembunyi. Karena kekuasaan menurut Gaventa merupakan kekuatan untuk kepentingan pribadi, salah satunya dengan mempertahankan kekuasaan dan privilege dari kepentingankepentingan. ${ }^{28}$ Kepentingan yang dimaksud pada konteks ini ialah kemampuan petahana mereduksi hasrat politik orang lain dalam kontestasi pilkada. Adanya politik uang atau mahardalam pencalonan kepala daerah adalah sebab bakal calon lain gagalmendapat rekomendasi dari partaikarena kalah memberi mahar daripasangan lain. ${ }^{29}$ Proses rekruitment calon kepala daerah dengan mahar terhadap partai politik sebagai cost politic. Selain menunjukkan pragmatisme partai politik namun fenomena dari perspektif bentuk kekuasaan tersembunyi dimaknai sebagai cara seseorang untuk membendung munculnya calon lain.

Bentuk kekuasaan yang tersembunyi initidak hanya berasal dari tindakan aktor tapi juga beroperasi sebagai jaringan kekuasaaan yang mendefinisikan 'cara kerja sesuatu' di balik layar. ${ }^{30}$ Hidden power berfokus pada kontrol aktual atas pengambilan keputusan, dan bagaimana aktor dan institusi yang kuat mempertahankan pengaruhnya. ${ }^{31}$ Dalam persepktif teori powercube bahwa orang-orang atau lembaga-lembaga yang mengendalikan kekuasaan tertentu sebagai proteksi pengaruh dengan mengendalikan siapa yang sampai pada pengambilan keputusan dan apa yang ada dalam agenda. Termasuk bagaimana petahana mengendalikan para elit partai politik untuk menentukan

${ }^{28}$ Institute of Development Studies, "Power Pack: Understanding Power for Social Change”, 1-90(2009), hlm. 11

${ }^{29}$ Ratnia SolihahdanSiti Witianti,Op.Cit, hlm. 22

${ }^{30}$ MaroPantazidou, "What Next for Power Analysis? A Review of Recent Experience with the Powercube and Related Frameworks",IDS Working Papers (August 2012), hlm. 12

${ }^{31}$ CeciliaLuttrellet.al, Loc.cit.

Jurnal TAPIs Vol. 14 No.02 Juli-Desember 2018 


\section{Andi Muh. Dzul Fadli, dkk: KEMENANGAN PETAHANA....}

dukungannya meskipun terkesan mengabaikan aspirasi grassrootsdalam mendorong pilihannya.

Dinamika ini beroperasi pada banyak tingkatan untuk dikecualikan dan mendevaluasi keterwakilan kelompok-kelompok lain yang kurang kuat termasuk seorang bakal calon dan masyarakat lokal.Sementara dalam kekuasaan yang tersembunyi (hidden power) yang menjadi target utama bukanlah siapa yang akan diusung, karena hal tersebut sudah memilikikepastian politik, yaknidukungan masyarakat, tetapi "transaksi apa yang dilakukan antara aktor dan voters", "apa yang akan dilakukan setelah kemenangan diperoleh". Hal tersebut terkait dengan keuntungan apa, posisi apa, dan bargaining apa yang akan ditindaklanjuti setelah kemenangan diperoleh. ${ }^{32}$

Bentuk kekuasaan yang tersembunyi lainnyayang paling sering menjadi kekuatan petahana ialah politisasi birokrasi melalui mobilisasi aparatur sipil negara (ASN). Di Pilkada serentak 2018, pelanggaran terkait keterlibatan ASN mengalami peningkatan dengan angka 721 kasus. Sementara itu, Badan Pengawas Pemilu (Bawaslu) telah menindaklanjuti sekitar 500 pelanggaran ASN di Pilkada serentak 2018. Dari pelanggaran ASN tersebut, ada yang sudah dipidanakan.Ambisi promosi jabatan, alasan senioritas di lingkungan birokrasi dan kedekatan secara personal antara ASN dengan calon petahana yang menjadikan sebab ketidaknetralan $\mathrm{ASN} .{ }^{33}$ Hidden power adalah alat penguasa untuk mempertahankan status quo-nya. ${ }^{34}$

Selain daripada itu, salah satu pilar dalam pelaksanaan pilkada langsung yang rentan terkooptasi oleh kepentingan petahana ialah ketidaknetralan penyelenggara pemilu. Hal ini sulit untuk dihindari oleh setiap kontestan. Sebab kemampuan petahana untuk memproteksi para penyelenggara pemilu

${ }^{32}$ JohnGaventa,"Finding the Spaces for Changes: A Power Analysis"IDS Bulletin, 37(6), 23-33 (November 2006), hlm. 29

${ }^{33}$ Anwar Saragihdan Barry Calvin Ginting,Op.Cit., hlm. 352

${ }^{34}$ Abd. Halim,Op.cit.,hlm. 67

Jurnal TAPIs Vol. 14 No.02 Juli-Desember 2018 


\section{Andi Muh. Dzul Fadli, dkk: KEMENANGAN PETAHANA....}

terbentuk secara alamiah oleh banyaknya gesekan organisasi civil society dan tingginya biaya setiap calon penyelenggara untuk terpilih sebagai komisioner. Sehingga keadaan tersebut, memaksa calon komisioner untuk melakukan kontrak politik terutama kepada calon petahana akibat adanya tradisi mahar dalam proses seleksi penyelenggara pemilu.

Dengan demikian, kemampuan petahana untuk mereduksi kesempatan atau preferensi orang lain pada konteks pilkada serentak, secara empirik dapat dilakukan dengan memonopoli atau mendominasi dukungan dari partai politik pada proses kandidasi. Selain itu, mobilisasi ASN untuk kepentingan politik kekuasaan dan adanya ketergantungan penyelenggara pemilu pada saat proses seleksi sehingga hal tersebut dimanfaatkan oleh para petahana. Oleh karena itu, fenomena-fenomena tersebut di atas merupakan bentuk-bentuk pengoperasian kekuasaan yang tersembunyi (hidden power) yang dilakukan oleh petahana.

\section{Kekuasaan yang Tidak Terlihat (Invisible Power)}

Bentuk kekuasaan yang tidak terlihat dapat digunakan pada demokrasi di daerah khususnya pada konteks pilkada. Dialektika kekuasaan di daerah yang secara kasat mata tidak terbaca oleh publik dapat dianalisis dengan menggunakan bentuk kekuasaan yang tidak terlihat (invisible forms of power). Secara kontekstual bahwa kekuasaan ini merupakanpiranti petahana untuk meningkatkan elektabilitas oleh konstituen. Mengikuti pendapat Luttrell, Bird, Byrne, \& Carter (2007)bahwa petahana dapatmenginternalisasikan norma dan nilai masyarakat yang dapat menyebabkan individu secara tidak sadar mengontrol perilaku mereka sendiri untuk memenuhi harapan sosial. ${ }^{35}$ Masyarakat kehilangan kesadaran karena terbius oleh nilai-nilai dan ideologi penguasa. ${ }^{36}$

\footnotetext{
${ }^{35}$ CeciliaLuttrellet.al, Loc.Cit

${ }^{36}$ Institute of Development Studies, Loc.cit.
} 


\section{Andi Muh. Dzul Fadli, dkk: KEMENANGAN PETAHANA....}

Hal tersebut dapat dilacak melalui momen-momen politik baik pada tingkatan nasional dan tingkatan di daerah. Sebagai contoh bagaimana para kandidat berlomba untuk merebut dan menggalang dukungan dari tokoh-tokoh agama dan adat pada etnis tertentu. Menggunakan peran elit terutama dari kalangan agamawan dan pemangku adat adalah pilihan yang realistis yang coba dijalankan oleh setiap kandidat, tidak terkecuali oleh petahana. Invisible powerdapat membentuk kepercayaan, perasaan diri, dan penerimaan status quo terhadap individu. Menanamkan nilai-nilai dan ideologi dalam tinjauan invisible power dikarenakan karakteristik yang pluralistik baik pada konteks agama dan suku bangsa di sebuah daerah.

Petahana melalui instrumen agama misalnya menjadi alat propaganda elit untuk memuluskan kepentingan politik, dimana nilai-nilai spiritualitas disebarluaskan ke masyarakat. Pada praktik invisible power, petahana menggunakan elit politik agama dan adat, sebab nilai-nilai agama dan tradisi lokal masyarakat menjadi faktor kuat untuk 'mengelabui' masyarakat di daerah. ${ }^{37}$ Selain itu, menggunakan para elit tersebut secara taktis dianggap lebih efisien dan efektif dalam menggalang dukungan dari beberapa kalangan tertentu. Selain itu, kemampuan petahana tersebut dalam tinjauan teori kekuasaan sebagai bentuk 'power over'yang mengacu pada kemampuan untuk mempengaruhi tindakan dan menggunakannya untuk menguasai pihak lain. Dikarenakan juga konsep 'power over'sebagai hubungan asimetris antara dua atau beberapa aktor. $^{38}$

Peranan tokoh masyarakat baik dari pemuka agama dan pemangku adat dalam momen politik. Secara antropologis, penggunaan nilai-nilai dan ideologi melalui elit politik yang berbasis agama dan daerah adalah suatu keniscayaan sebagai modalitas politik dan konsekuensi dari stratifikasi sosial-

\footnotetext{
${ }^{37}$ Abd. Halim, Op.cit., hlm. 68
}

${ }^{38}$ KeithDowding, Encyclopedia of Power,(California: SAGE Publications, Inc. 2011), hlm. 521

Jurnal TAPIs Vol. 14 No.02 Juli-Desember 2018 


\section{Andi Muh. Dzul Fadli, dkk: KEMENANGAN PETAHANA....}

masyarakatmelalui rayuan simbolik.Sehingga di dalam pilkada langsung,tokoh-tokoh tersebut senantiasa mendapat perhatian para petahana dan politisi lainnya guna sebagai mesin pendongkrak suara pada setiap daerah pemilihan. Selain itu, melalui proses sosialisasi, budaya dan ideologi mengabadikan eksklusi dan ketidaksetaraan dengan mendefinisikan apa yang dapat diterima oleh masyarakat.

Fenomena tersebut, bila dianalisis dengan menggunakan konstruksi teori modal Bourdieu, maka setiap subyek peserta pemilu(kandidat dan partai politik) berpacu untuk menggunakan modal simbolik melalui agamawan dan pemangku adat sebagai cerminan invisible power. Adanya seseorang atau kelompok yang direpresentasekan sebagai simbol yang memiliki kekuatan dalam mengkonstruksi realitas, mampu menggiring orang untuk mempercayaidan mengubah pandangan orang tentang realitas seseorang atau sekelompok orang. Modus pengoperasian praktik kekuasaan yang tidak terlihat ini melalui internalisasi ketidakberdayaan masyarakat. ${ }^{39} \mathrm{Di}$ dalam masyarakat daerah yangmemegang akar tradisi, mereka lebih sukadan bisa diarahkan atas para tetuahagama, atau tokoh agama dan tokohmasyarakat melalui arahan dan instruksi lisan. ${ }^{40}$

Tipologi masyarakat merupakan acuan dasar para kontestan politik dengan membuat pemetaan dalam menyerap dukungan dari bawah. Bila kehidupan sosial-masyarakat lebih mengedepan pemberian kekuasaan secara simbolik, maka relasi emosional masyarakat lebih mudah terpetakan sehingga apa yang menjadi instruksi seorang elit politik agama atau pemangku adat menjadi lebih efektif dan efisien. Oleh karena itu, menjamurnya para kontestan politik meminta restu dan mempublikasi secara tidak langsung dukungan seorang tokoh, maka rasa kebersamaan masyarakat untuk mengerucutkan dukungannya akan terbangun.

\footnotetext{
${ }^{39}$ Abd. Halim, Op.cit., hlm. 70

${ }^{40}$ Abdul Chalik, Op.cit., 373
} Jurnal TAPIs Vol. 14 No.02 Juli-Desember 2018 


\section{Andi Muh. Dzul Fadli, dkk: KEMENANGAN PETAHANA....}

\section{Penutup}

Fenomena kontestasi pilkada serentak di Indonesia yang telah dilaksanakan sejak tahun 2015, 2017, dan 2018 diikuti oleh berbagai latar belakang calon termasuk para petahana yang masih diperbolehkan oleh undang-undang. Adanya persentase kemenangan para petahana diberbagai pilkada pada dasarnya disebabkan oleh pengoperasian dari bentuk-bentuk kekuasaan dari perspektif teori kubus kekuasaan (powercube) antara lain: Pertama, bentuk kekuasaan yang terlihat (visible power) seperti kesempatan untuk menarik simpati masyarakat melalui jualan program pembangunan yang telah dilaksanakan sebagai investasi politik. Kedua, bentuk kekuasaan yang tersembunyi (hidden power) ialah politisasi birokrasi melalui mobilisasi aparatur sipil negara, monopoli dukungan partai politik, dan kooptasi terhadap penyelenggara pemilu. Ketiga, bentuk kekuasaan yang tidak terlihat (invisible power), melalui peranan pemuka agama dan pemangku adat untuk menanamkan nilai-nilai dan ideologi adalah modalitas politik petahana sebagai konsekuensi dari stratifikasi sosial-masyarakat.

Dalam berbagai momen pemilu seperti pemilihan kepala daerah, ada banyak strategi kontestan untuk memenangkan pertarungan politik kekuasaan di daerah. Karena secara konseptual, kontestasi pilkada yang secara langsung tersebut menimbulkan konsekuensi adanya komunikasi secara langsung di antara berbagai elemen baik calon, partai politik, masyarakat dan lain sebagainya. Sehingga adanya pengoperasian bentuk-bentuk kekuasaan adalah kemustahilan untuk dihindari, akan tetapi setiap kontestan dituntut pula untuk konsekuen (taat asas) terhadap regulasi dan norma-norma agar pilkada benar-benar melahirkan kepala daerah yang berintegritas dan berprestasi dalam menahkodai jalannya pemerintahan.

\section{Daftar Pustaka}

Arianto, B. (2011). Analisis Penyebab Masyarakat tidak Memilih dalam Pemilu. Jurnal Ilmu Politik Dan Pemerintahan, 1(1), 


\section{Andi Muh. Dzul Fadli, dkk: KEMENANGAN PETAHANA....}

$51-60$.

Azanella, L. A., \& Dewi, R. K. (2018, July 26). 64 Kepala Daerah Petahana Terpilih pada Pilkada Serentak 2018. Retrieved from https://nasional.kompas.com/read/2018/07/26/18520301/64kepala-daerah-petahana-terpilih-pada-pilkada-serentak-2018

Azis, A. (2018, June 26). Calon Kepala Daerah Pengusaha Dominasi Pilkada 2018. INews.Id. Retrieved from https://www.inews.id/news/read/161981/calon-kepaladaerah-pengusaha-dominasi-pilkada2018?sub_slug=nasional

Beli, W. S. (2016). Hidden Power dalam Politik Pemekaran di Nusa Tenggara Timur. Jurnal of Government - JOG, 2(1), 117.

Chalik, A. (2015). Elite Lokal Berbasis Pesantren Dalam Kontestasi Pemilihan Kepala Daerah Di Jawa Timur. KARSA: Jurnal Sosial dan Budaya Keislaman, 23(2), 363381.

Damaledo, Y. D. (2018, June 28). 11 Petahana Unggul Lawan Kotak Kosong Versi Hitung Cepat KPU. Tirto.Id. Retrieved from https://tirto.id/11-petahana-unggul-lawan-kotakkosong-versi-hitung-cepat-kpu-cM9Y

Dowding, K. (Ed.). (2011). Encyclopedia of Power. California: SAGE Publications, Inc.

Gaventa, J. (2006). Finding the Spaces for Changes: A Power Analysis. IDS Bulletin, 37(6), 23-33.

Halim, A. (2014). Politik Lokal: Pola, Aktor \& Alur Dramatikalnya (Perspektif Teori Powercube, Modal dan

Jurnal TAPIs Vol. 14 No.02 Juli-Desember 2018 


\section{Andi Muh. Dzul Fadli, dkk: KEMENANGAN PETAHANA....}

Panggung). Yogyakarta: LP2B.

Institute of Development Studies. (2009). Power Pack: Understanding Power for Social Change, 1-90.

Khoiron, \& Siboy, A. (2018). Kemenangan Petahana (Incumbent) pada Pilkada 2015 di Kota Surabaya dan Kabupaten Malang: Strategi Politik dan Marketing Politik. Jurnal Ilmu Administrasi Publik, 3(1), 1-10.

Kompas TV. (2018, June 27). Ini dia Para Petahana Pilkada 2018. Tribunnews.com. Retrieved from http://www.tribunnews.com/nasional/2018/06/27/ini-diapara-petahana-pilkada-2018

Luttrell, C., Bird, K., Byrne, S., \& Carter, J. (2007). The Power Cube Explained. The Poverty-Wellbeing Platform, 3(November), 1-5.

Mandiri, A., \& Tanjung, E. (2015, December 10). LSI: 70 Persen Petahana Menang dalam Pilkada Serentak. Suara.Com. Retrieved from https://www.suara.com/news/2015/12/10/161341/lsi-70persen-petahana-menang-dalam-pilkada-serentak

Marijan, K. (2010). Sistem politik Indonesia: Konsolidasi Demokrasi Pasca-Orde Baru. Jakarta: PT. Kencana Prenada Media Group.

Merdeka. (2018, June 29). KPU sebut partisipasi pemilih di Pilkada 2018 capai 73,24 persen. Merdeka.Com. Retrieved from https://www.merdeka.com/politik/kpu-sebutpartisipasi-pemilih-di-pilkada-2018-capai-7324-persen.html

Moon, B. E., Birdsall, J. H., Ciesluk, S., Garlett, L. M., Hermias, J. J., Mendenhall, E., ... Wong, W. H. (2006). Voting

Jurnal TAPIs Vol. 14 No.02 Juli-Desember 2018 


\section{Andi Muh. Dzul Fadli, dkk: KEMENANGAN PETAHANA....}

Counts: Participation in the Measurement of Democracy. Studies in Comparative International Development, 41(2), 3-32.

Pantazidou, M. (2012). What Next for Power Analysis? A Review of Recent Experience with the Powercube and Related Frameworks. IDS Working Papers (Vol. 2012).

Prasetia, A. (2017, April 20). Ini 171 Daerah yang Gelar Pilkada Sserentak 27 Juni 2018. Retrieved January 21, 2018, from https://news.detik.com/berita/d-3479819/ini-171-daerahyang-gelar-pilkada-serentak-27-juni-2018

Rohman, T., Astuti, P., \& Fitriyah. (2013). Strategi Pemenangan Petahana dalam Pemilihan Umum Kepala Daerah Kabupaten Ngawi 2010. Journal of Politic and Government Studies, 446-461.

Saragih, A., \& Ginting, B. C. (2017). Proyeksi Mewujudkan Pemilu Berintegritas Lewat Netralitas Aparatur Sipil Negara di Pilkada Serentak 2018. Jurnal Bawaslu, 3(3), 351-362.

Solihah, R., \& Witianti, S. (2017). Permasalahan dan Upaya Mewujudkan Pemilu Demokratis di Indonesia Pasca Reformasi. Jurnal Bawaslu, 3(1), 13-33.

Tiran, R. (2013). Kemenangan Petahana dan Demokrasi Lokal dalam Pilkada Kabupaten Kupang Tahun 2013. Tesis Fakultas Ilmu Sosial dan Ilmu Politik Universitas Airlangga.

Yahya, M. R. (2018). Faktor yang Mempengaruhi Kemenangan Jefry Noer dan Ibrahim Ali di Pilkada Kabupaten Kampar, $1(1), 42-49$.

Yusra, A., \& Darmawan, I. (2017). Kepentingan Petahana dalam Manipulasi Pilkada Labuhan Batu Selatan 2015. Jurnal

Jurnal TAPIs Vol. 14 No.02 Juli-Desember 2018 
Andi Muh. Dzul Fadli, dkk: KEMENANGAN PETAHANA....

Wacana Politik, 2(2), 74-87.

Jurnal TAPIs Vol. 14 No.02 Juli-Desember 2018 